\title{
Socio-Energy Systems Design: A Policy Framework for Energy Transitions
}

Clark A. Miller,* Jennifer Richter, and Jason O’Leary

Consortium for Science, Policy \& Outcomes

Arizona State University

P.O. Box 875603

Tempe, AZ 85287-5603

*Corresponding author: clark.miller@asu.edu; 480-965-1778 


\title{
Socio-Energy Systems Design: A Policy Framework for Energy Transitions
}

\begin{abstract}
In the context of large-scale energy transitions, current approaches to energy policy have become too narrowly constrained around problems of electrons, fuel, and carbon, the technologies that provide them, and the cost of those technologies. Energy systems are deeply enmeshed in broad patterns of social, economic, and political life and organization, and significant changes to energy systems increasingly are accompanied by social, economic, and political shifts. Energy policy is therefore, in practice, a problem of socio-energy system design. In this article, we offer a definition of socio-energy systems, reconceptualize key questions in energy policy in terms of socio-energy systems change, analyze three case studies of energy policy development as problems of socio-energy systems design, and develop recommendations for rethinking energy policy and governance in the context of socio-energy systems transitions.
\end{abstract}

Keywords: socio-energy system, governance, society, transition, design

\section{Introduction}

Over the past quarter century, extensive research has documented that energy - typically represented as a technological and economic phenomenon-is also fundamentally social in its origins and organization, woven into societal, geographic, and geopolitical arrangements at scales from the individual to the planet (for recent reviews, see Sovacool 2014, Miller and Richter 2014, Zimmerer 2011). To date, however, work in the energy social sciences has had little impact on energy policy. There are a few notable exceptions. In parts of Europe, policy and planning increasingly recognizes the significance of the 
societal facets of energy for both building public support for energy policies (Wustenhagen et al. 2007) and in designing future energy systems by incorporating, e.g., innovative ownership models (Meyer 2007) and diverse public values (Trutnevyte et al. 2011). Similarly, civil society organizations are increasingly pushing energy projects in developing countries to attend much more closely to the design challenge of linking the delivery of energy services to concrete strategies for alleviating poverty (Poor People's Energy Outlook 2014).

In most of the world, however, and certainly in the United States, whose perspectives largely dominate global energy markets and the energy projects of the major development banks, energy policy remains a largely techno-economic problem. What we might term the human and social dimensions of energy barely rate a mention-let alone receive detailed, substantive treatment — in, for example, recent high profile US energy policy analyses, such as the National Academies' America's Energy Future (2008), the Department of Energy's Quadrennial Technology Review (2012), or the Department of State's review of the Keystone XL Pipeline (2014). Nor do insights from the energy social sciences factor significantly into more routine energy policy analyses and decisions, e.g., in the permitting of drilling, the regulation of electricity markets, or the development of renewable energy mandates. Instead, energy policy routinely relies on caricatured, tacit or implicit, not-reflected-upon models of people and societies that rarely conform well to reality (Wynne 2005).

In this article, we propose that energy policy institutions adopt a more expansive conceptual framework that integrates social considerations more effectively into energy analysis and decision-making. We term this framework socio-energy systems design. In 
proposing this framework, we respond specifically to Sovacool's call in the inaugural issue of Energy Research and Social Sciences for new ways to communicate effectively about social science research in mainstream energy conversations (Sovacool 2014). Our objective is to shift the framing of energy policy from what we consider an overly narrow conventional approach — what technologies do we need to deliver energy, at what price, and with what carbon or other environmental costs - toward a perspective that recognizes that the conceptualization and design of energy systems is, fundamentally, an exercise in the simultaneous conceptualization and design of diverse social arrangements. ${ }^{1}$ Through time, energy policy choices reconfigure societies, even as societies reconfigure energy systems, especially at moments when new energy systems are brought into being or during periods when existing systems are significantly rearranged through the persistent evolution, growth, and embedding of energy into human affairs (Mitchell 2011, Huber 2013). Thus, we argue, the social dimensions of energy systems are particularly salient for energy policy choices in the context of large-scale energy transitions, such as those currently underway in global energy markets due to the rise of hydraulic fracturing technologies for oil and gas extraction, the deployment of renewable energy generation to address climate change, and the development of alternative fuel, hybrid, and electric vehicles.

Contemporary energy transitions are reshaping not only the technologies and economics of energy but also physical and social geographies, social meanings, and the political organization of energy production, distribution, and consumption. Not surprisingly, around the globe, these changes have catalyzed growing socio-political resistance to energy policy and energy system change, with virtually every major form of energy tech-

\footnotetext{
1 Jasanoff and her colleagues term this co-production. See Jasanoff 2004, Jasanoff and Kim 2009.
} 
nology confronting social protest and political controversy (Abramsky 2010). Only by reconceiving energy policy in more social terms, we believe, can the world hope to lessen conflict over energy transformations in the coming quarter century (Miller et al. 2013). The framework of socio-energy systems design aims to accomplish this task, reframing energy policy debates as debates not just about how to produce energy but about what energy production and consumption means for the diverse groups and communities who inhabit energy systems.

Most energy social scientists will not be surprised by the basic outlines of socioenergy systems design as an energy policy framework. The framework is heavily indebted to theories of sociotechnical systems: interconnected, integrated systems that link social, economic, and political dynamics to the design and operation of technological systems. Theories of sociotechnical systems have been used extensively and productively for some time to explain historical developments in the energy sector (e.g., Hughes 1983, Nye 1999, 1990, Hecht 2012, 2011, 1998, Hirsh and Jones 2014) and to analyze strategies for fostering sustainable energy transitions (e.g., Geels 2010, Geels and Verhees 2011, Marathe et al. 2011). Building on theories of sociotechnical systems and the coproduction of technology and society (Jasanoff 2004), our objective is to establish socioenergy systems as a forward-looking design concept that can alter the lenses through which policymakers view energy policy choices, expand the range of analyses conducted to support those decisions, and enable publics to more effectively imagine and evaluate what energy policy may mean for individuals, families, and communities.

In the article's first section, we define the concept of socio-energy systems and illustrate how it can be applied to reformulate the goals and objectives of energy policy, as 
well as how its use as a lens transforms key ideas in energy policy, such as energy transitions and energy justice. In the second section, we offer three short case studies of current energy policy choices, drawn from our own research, that highlight the value of reframing energy policy choices as problems of socio-energy system design. In the third section, we offer four strategies for incorporating the concept of socio-energy systems design into energy policy practices and institutions. Although our argument could in principle be applied anywhere, in this article, we draw primarily on examples and case studies from the United States. We have made this choice in part because the United States is where we conduct our research and are most knowledgeable of the details of energy policy. But it is also, as we have suggested above, because US conceptualizations of energy policy are highly influential in global energy markets and institutions and because the United States is a central player in global energy transitions. Reframing US energy policy debates therefore has the potential to pay dividends not only in the United States but also in many other parts of the world.

\section{Rethinking Energy Policy as Socio-Energy Systems Design}

\subsection{Defining Socio-Energy Systems}

What do we envision when we suggest reframing the object of energy policy analysis and decision-making as an exercise in the design of socio-energy systems? First and foremost, we envision a way of recognizing that energy systems involve the work, behavior, and choices of many different kinds of people. Perhaps ironically, one of the best places to see energy and people in an integrated fashion is in children's books written a half century ago, not so long after the electrification of many homes and farms in the United 
States and the rise of the automobile as a common family purchase. Richard Scarry's books, in particular, What Do People Do All Day? and Cars and Trucks and Things That Go, offer a vibrant picture of diverse individuals, families, and communities living with new forms of energy. In Scarry's images and narratives, energy technologies come to life not just as assemblages of machinery but also as integral elements in the daily experiences of diverse people: workers, homeowners, beach goers, students, a "lazy fellow," and many more. Individuals in the books mine coal, transform it into electricity, and use it to power televisions, vacuums, and backyard barbecues. They harness the movement of water to transport trees and convert them into lumber for houses and boats and paper, as well as to power lights and irrigate crops. They drive cars and trucks and fly airplanes. They wire electrical systems in houses, retrofitting some and constructing others with wires already inside the walls. People's everyday lives and livelihoods - the activities that give them purpose and identity and that enact and animate the community of Busy Town-are thoroughly wrapped up in systems for producing and consuming energy. ${ }^{2}$ Scarry's imaginative world offers a lens through which it becomes possible to see energy policy choices markedly differently from conventional energy analyses. In the world depicted in the National Academies recent report, America's Energy Future, for example, the only facets of the future that seem to matter are which technologies to choose, how much to pay for them, and how much that will reduce carbon emissions

\footnotetext{
${ }^{2}$ Scarry's images can be seen online: power plant (http://3.bp.blogspot.com/-i7ENiBDyOw/Tgn6HMOQwjI/AAAAAAAAAV8/u9wb1r7v0vg/s1600/Electricity+generation+ production+richard+scarry+what+do+people+do.jpg); coal mine (http://scienceblogs.com/worldsfair/wp-content/blogs.dir/389/files/2012/04/i1e3c3801c1d14d8203e4a04f37cd97d1-digging1small.jpg); river transport of logs (http://exampleschildrensbooks.files.wordpress.com/2012/06/scarry-trees.jpg).
} 
(NAE 2008). The world is stripped bare of its human dimensions, and people are all but entirely absent from this image of the country's future, neglecting that the people of America's future will not only shape their energy systems but also inhabit forms of life partly configured by them (Winner 1986). Energy policy choices shape not just technological trajectories but trajectories in how people envision and construct themselves and their relationships to one another and to the world (Sovacool and Brossman 2013, Hirt 2012, Smith 1994). Yes, in the world made visible in Scarry's imagery, energy policies shape the technologies and the costs of electricity flowing through the wires; yet, they also act on all other aspects of the images, too.

Scarry's images make visible a host of dimensions of energy policy that social scientists have gone on to study in detail. The electrification of the home was as much about women's roles as homemakers and broader gender dynamics in household technology use as it was about new devices and infrastructures (see, e.g., Cowan 1983, Nye 1990). Education changed, too. Like the young pig on the roof of Scarry's power plant, students now learn Ohm's law in physics classes. More broadly, electrification, along with the birth of the chemical industry, helped dramatically upgrade the role of engineering education on university campuses in the late $19^{\text {th }}$ and early $20^{\text {th }}$ centuries and, a few decades later, fueled the rise of Stanford and MIT as intellectual powerhouses on the respective strengths of their electrical engineering departments (see, e.g., Leslie and Hevly 1985). And workplaces and work changed, too, as societies responded to workers experiences ("It's hot in here.") in new industrial settings ushered in by electrification with new forms of social research and social regulation and welfare, including safety standards and disability insurance (see, e.g., Wagner and Wittrock 1991). 
Indeed, energy choices arguably contribute to virtually every facet of modern societies, up to and including fundamental constitutional arrangements. As recent policy debates illustrate, people's ideas about energy are bound up with basic notions about the proper arrangements of individuals, markets, and governments in modern societies. In the United States and Germany, for example, recent energy efficiency standards precluding the sale of incandescent light bulbs have become for key segments of the electorate a rallying cry for freedom and liberty against government intrusion into the economy (Howarth and Rosenow 2014). These claims draw not from some profound material impacts of compact fluorescent or LED bulbs. These replacements require at most only minor adjustments to social and technological arrangements and generally result in significant consumer cost savings. Rather, the idea that energy choices are constitutional in scope and import derives from ways of imagining the relationship between technology and politics that imbue energy choices with deep societal meaning (Jasanoff and Kim 2013, 2009). Similarly, conflicts over distributed solar energy generation in the US Southwest have sparked over whether government regulated utilities should have the right to protect their monopoly on energy sales from direct competition by creating barriers to the adoption of rooftop energy systems (Bird et al. 2013, Rucinski and Kaye 2014). Such monopolies are a key constitutional provision that has made possible, worldwide, the construction of the kind of technological systems represented by Scarry's image of the coal-fired power plant as the central organizing element of modern electrical systems (Insull 1915), but whose possibility is now under threat from new kinds of socio-energy arrangements (Graffy and Kihm 2014). 
To facilitate energy policy analyses and decisions that can account for the multifaceted human and social dimensions of energy visible in Scarry's imagined world—and in our own real equivalents — we argue for adopting the concept of socio-energy systems as a design framework. At the most basic level, we define socio-energy systems as sets of interlinked arrangements and assemblages of people and machines involved in the production, distribution, and consumption of energy, in their supply chains, and in the lifecycles of their technologies and organizations. Simple analytics for socio-energy systems follow networks and systems of technological components, tracking the people and organizations connected to them (Mulvaney 2013). More complex analytics recognize that, at times, the linkages in socio-energy systems may flow entirely through social dynamics, that socio-energy systems dynamically shape and get shaped by the larger social, cultural, and political contexts in which they are embedded, and that people and organizations are complex entities - with histories, identities, and cultures - that require careful and sophisticated analysis (Mitchell 2011, Nye 1990, Perrow 1984). In either case, what is significant for our argument is the idea that it is these rich social worlds that energy policy acts upon and thus the question confronting energy policy-especially in the context of largescale energy transitions - is which kind of world one wants to create for the future.

\subsection{Energy Policy Goals and Objectives}

Adopting a socio-energy systems design lens, we argue, reconfigures core elements of energy policy. This includes, crucially, the goals and objectives of energy policy. It is an 
oversimplification, but perhaps not too much of one, to suggest that energy policy currently focuses on three relatively narrow goals: to produce and distribute sufficient energy to reliably meet demand, to minimize the cost of that energy, and to achieve environmental goals associated with energy production, such as low atmospheric emissions of carbon or other pollutants. A socio-energy systems lens does not necessarily reduce the significance of these objectives. Rather, such a lens does two things. First, it acknowledges that these goals may need to be balanced by other considerations, such as social changes or risks that may arise as a result of energy transitions. Thus, for example, while energy policy analyses of fracking have focused most closely on water quality issues, communities experiencing a rapid surge of fracking have expressed a much wider array of social and economic concerns that energy policies have tended to ignore - contributing to social alienation, civic protest, and even ballot initiatives aimed to ban the practice.

Second, a socio-energy systems lens opens up a considerably larger range of other potential goals that energy policy could consider and address, potentially including any significant social goal impacted by choices in the design of socio-energy systems. For example, rising inequality is a problem confronting most nations (Chin and Culotta 2014). Since energy is a well-known factor in economic development — and, as we observe in the first case study below, energy technologies are always embedded in intricate socioeconomic arrangements whose design is an implicit component of energy policy-energy policy could explicitly target the reduction of social and economic inequality as a goal. Indeed, historically, regulators have prized equality as a core principle in the design of electrical utilities, although as we also suggest in the first case below, they may need to revisit the strategies used to pursue this goal in the context of today's energy transitions. 
A socio-energy systems lens also encourages more sophisticated treatment of social goals within energy policy. In recent years, for example, advocates of US energy policies have focused a great deal of attention on job creation in the energy sector. Attention to job creation is no surprise given current US unemployment rates. Yet, as we will discuss in the second case study below, job creation is a relatively poor proxy for the deeper goals that communities ultimately care about, such as health, stability, and wellbeing. In the oversimplified narratives of US energy policy, job creation offers communities access to new wealth and to the stability that comes from employment. But jobs can be unsafe. Influxes of workers can stress social support infrastructures and exacerbate social conflict. And the vicissitudes of energy markets can be volatile, confronting communities with destructive boom and bust cycles. What matters is not just job creation but what kinds of jobs, who secures them, how long they last, and community resilience and innovation in the face of dynamic energy markets. All of these things can be measured and assessedalongside job creation - if we reformulate and reframe energy policy in terms of the analysis and design of socio-energy systems.

\subsection{Energy Transitions}

Talk of energy transitions is common to energy policy discourse. In general, the language of energy transitions is used to describe shifts in the fuel source for energy production and the technologies used to exploit that fuel (Laird 2013). Thus, one might talk about the transition from wood to fossil fuels or from gasoline cars to electric vehicles. When envisioned in terms of socio-energy systems, however, fuel and technology become less diagnostic of energy transitions (Miller et al. 2013). Replacing a coal-fired power plant with a 
gas or nuclear-fired equivalent may have little impact on the overall energy regime, e.g., a centralized electrical utility operating as a regulated monopoly energy producer and distributor, even if it may bring local perturbations to those who live near the facilities in question or along relevant supply and waste chains. Instead, the phrase 'energy transitions' comes to refer to significant transformations in socio-energy systems (Elzen et al. 2004). Thus, as we describe in the first case study below, the transition from a purchase model to a lease model in the financial arrangements surrounding rooftop photovoltaic systems in the US Southwest is rapidly transforming socio-energy systems - turning large numbers of energy consumers into producers - even though the technology and fuel in question are exactly the same.

In redefining energy transitions in terms of socio-energy systems design, what all three cases below illustrate, in particular, is the significance of careful attention to the micro-scale socio-economics of energy technologies. Socio-economic arrangements are significant not only in terms of predicting and explaining the social and market dynamics of new energy technologies — offering significant insight into processes of both commercial uptake and resistance - but also in understanding the social outcomes that flow from energy transitions. For example, to return to the theme of inequality discussed briefly above, our research shows that the micro-scale socio-economics of current solar energy policies in the US Southwest are, in fact, exacerbating inequality. Unequal outcomes that aggravate existing social and economic disparities are hardly unknown in the energy sector, of course (for a recent treatment of the subject, see, e.g., Ottinger 2013). What an approach to energy transitions grounded in socio-energy systems adds is the possibility to 
explicitly anticipate and incorporate a robust analysis of such outcomes into the design of energy policies from the outset, rather than working to correct them after the fact.

\subsection{Energy Justice}

Building on the two prior ideas, we can also construct an enhanced picture of energy justice. Energy justice is generally formulated in terms of access to energy, for good reason. Energy is considered a basic element of economic development, and something approximating 2 billion people worldwide either have no or limited access to modern forms of energy production. Yet, when considered in the context of socio-energy systems, access to energy is only one of many significant variables that determine just energy arrangements. Perhaps most obviously, the availability of energy in a community is meaningless if existing socio-technical arrangements do not allow people to effectively use that energy to upgrade their wellbeing (Poor People's Energy Outlook 2014). Amartya Sen has famously observed that most famines do not result from a lack of food but rather from social, political, and economic arrangements that prevent people from using the available food to satisfy their hunger (Sen 1983). Much the same can be said of energy. Even at the national scale, data show that different countries derive radically different levels of human development and wellbeing from the same levels of overall energy consumption (Steinberger and Timmons Roberts 2010), strongly suggesting that the details of socioenergy systems matter not just in terms of access but effective use.

More broadly, as we describe in more detail in the case studies below, justice in socio-energy systems is a question of both the distribution of human outcomes within these systems, the distribution of power and voice in energy decision-making, and the 
deeper relationships between energy and the kinds of societies we fashion through and around it (Miller 2014, Richter 2013, Mitcham and Rolston 2013). Across entire lifecycles - supply chains, production and distribution chains, and waste chains - transitions in socio-energy systems reconfigure a wide range of social outcomes, relationships, and power across individuals, groups, and communities (Rolston 2013). It is this normatively transformative feature of energy policy, especially in the context of large-scale energy transitions, which has led to widespread social protest and conflict surrounding contemporary energy policy. Having operated largely out of the public eye for decades, energy policy institutions today confront a new reality: publics increasingly are attentive to energy choices. We suggest that a framework of socio-energy systems analysis and design will serve energy policy institutions well in understanding and addressing the new realities of energy politics.

\section{Case Studies in Socio-Energy Systems Analysis and Design}

The previous section suggested that looking at energy policy in terms of socio-energy systems design had the potential to foster a richer and more accurate picture of the full potential and impacts of energy policy. Where traditional energy policy considers the human and social dimensions of energy to be externalities, a socio-energy systems framework internalizes these factors. Here we offer three brief case studies chosen from our research, each focused on a significant recent energy policy decision. The case studies re-express these decisions as exercises in socio-energy systems design to illustrate how such analyses may work and what additional insights such a perspective may offer to energy policymakers. 


\subsection{Design Choice \#1: Which Solar, Whose Benefits?}

Since the late 1990s, Arizona, like many other parts of the world has turned to solar energy as a solution to several energy problems. Also like many places, this choice has been presented as a choice between solar and older fuels, like coal and nuclear. The state regulatory body, the Arizona Corporation Commission, has explicitly argued for advancing solar energy as a tool for diversifying the technology and fuel base of state's energy supply and has implemented a series of policies encouraging solar energy development, including both utility-scale and distributed generation. Federal policy has also contributed to the growth of Arizona solar energy through tax credits for investments in solar energy by both individuals and companies. The American Reinvestment and Recovery Act funded the installation of solar energy systems on public buildings, such as schools, to help reduce government energy expenditures. Combined with falling prices for solar energy technologies, solar investment has heated up dramatically in the state. As of 2013, Arizona ranked second in the nation in terms of total solar energy installed, behind California. $^{3}$

In the past year, however, solar energy has become the subject of deep conflicts among Arizona's political institutions, elites, and publics. These conflicts have revealed that the choice confronting the state is not simply whether or not to "go solar"- the state's utilities will easily achieve their $15 \%$ targets under the Commission's renewable portfolio targets — but which model of solar-based socio-energy system to choose going forward. The diverse policies that have promoted solar energy in Arizona have catalyzed

\footnotetext{
${ }^{3}$ http://www.seia.org/research-resources/2013-top-10-solar-states
} 
the emergence of at least six distinct models of socio-energy systems design within the solar industry, each of which has strong advocates, a distinct vision of the future, and a track record of successful implementation. Table 1 illustrates some of the most significant dimensions of social variation across these models.

\begin{tabular}{|l|l|l|l|l|l|l|}
\hline & $\begin{array}{l}\text { Home } \\
\text { Rooftop, } \\
\text { Owned }\end{array}$ & $\begin{array}{l}\text { Home Roof- } \\
\text { top, Leased }\end{array}$ & $\begin{array}{l}\text { Utility- } \\
\text { Scale } \\
\text { Projects }\end{array}$ & $\begin{array}{l}\text { Community } \\
\text { Projects }\end{array}$ & $\begin{array}{l}\text { Business } \\
\text { Rooftops }\end{array}$ & $\begin{array}{l}\text { Public Enti- } \\
\text { ty Rooftops }\end{array}$ \\
\hline Typical Scale & $3-7 \mathrm{~kW}$ & $3-7 \mathrm{~kW}$ & $\begin{array}{l}20-300 \\
\text { MW }\end{array}$ & $0.5-5 \mathrm{MW}$ & $0.5-2 \mathrm{MW}$ & $0.5-5 \mathrm{MW}$ \\
\hline Owner & $\begin{array}{l}\text { Home } \\
\text { owners }\end{array}$ & $\begin{array}{l}\text { Leasing } \\
\text { company }\end{array}$ & Utility & Town or city & $\begin{array}{l}\text { Business or } \\
\text { Leasing } \\
\text { Company }\end{array}$ & Public entity \\
\hline Participants & $\begin{array}{l}\text { Home } \\
\text { owners }\end{array}$ & $\begin{array}{l}\text { Home own- } \\
\text { ers }\end{array}$ & Utilities & Residents & $\begin{array}{l}\text { Business } \\
\text { owners }\end{array}$ & $\begin{array}{l}\text { Schools and } \\
\text { government } \\
\text { agencies }\end{array}$ \\
\hline Beneficiaries & $\begin{array}{l}\text { Home } \\
\text { owners }\end{array}$ & $\begin{array}{l}\text { Home own- } \\
\text { ers and leas- } \\
\text { ing compa- } \\
\text { nies }\end{array}$ & Utilities & $\begin{array}{l}\text { Utilities and } \\
\text { residents }\end{array}$ & $\begin{array}{l}\text { Utilities and } \\
\text { businesses }\end{array}$ & $\begin{array}{l}\text { Utilities and } \\
\text { public enti- } \\
\text { ties }\end{array}$ \\
\hline Cost / kW & Highest & Medium & Lowest & Low & Low & Low \\
\hline $\begin{array}{l}\text { Source of } \\
\text { Investment } \\
\text { Capital }\end{array}$ & $\begin{array}{l}\text { Home } \\
\text { owner } \\
\text { savings }\end{array}$ & $\begin{array}{l}\text { Leasing } \\
\text { company } \\
\text { investors; } \\
\text { home owner } \\
\text { savings }\end{array}$ & $\begin{array}{l}\text { Rate } \\
\text { payers; } \\
\text { utility } \\
\text { investors }\end{array}$ & $\begin{array}{l}\text { Cities; munici- } \\
\text { pal bond hold- } \\
\text { ers; residents; } \\
\text { taxpayers; so- } \\
\text { cial investors }\end{array}$ & Businesses & $\begin{array}{l}\text { State bond } \\
\text { holders; tax- } \\
\text { payers }\end{array}$ \\
\hline Location & $\begin{array}{l}\text { House } \\
\text { rooftops }\end{array}$ & $\begin{array}{l}\text { House roof- } \\
\text { tops }\end{array}$ & $\begin{array}{l}\text { Rural } \\
\text { land }\end{array}$ & $\begin{array}{l}\text { Variety of ur- } \\
\text { ban sites }\end{array}$ & $\begin{array}{l}\text { Retail build- } \\
\text { ing rooftops }\end{array}$ & $\begin{array}{l}\text { Variety of } \\
\text { urban sites }\end{array}$ \\
\hline
\end{tabular}

Table 1. Varieties of socio-energy system design for Arizona solar energy developments

What Table 1 captures is the fact that energy policy choices have the potential to create vastly different societies. Advocates of distributed energy have long made this argument (Lovins 2002), but the challenge is much deeper. Major differences exist across these diverse models of socio-energy systems, including: the cost of produced energy; the geographies of energy construction; the sources of capital that invest in them; the financial beneficiaries of projects; those who pay for projects and bear risks; the future viability of utility business models; and the collective, emergent patterns of energy behavior among 
publics and energy users. Some of the more significant and illustrative examples of these differences include:

- Ownership, finance, and return on investment: Historically, utilities and operators of merchant power plants have dominated ownership of electricity generation in Arizona. Solar projects have significantly diversified ownership of energy facilities, including among homeowners, solar leasing companies, municipalities, businesses, and government agencies. Not surprisingly, this corresponds to a greater diversity of sources of capital for energy investments and of beneficiaries of return on those investments, allowing for a larger variety of investors and benefits to those investors. At the same time, many models threaten to reduce longterm utility revenues (Satchwell et al. 2014, Graffy and Kihm 2014).

- Location: The debate between centralized and distributed solar tends to focus on plants built in open desert regions and on household rooftops, but significant variation exists both at utility-scales, where the most extensive development of projects in Arizona has occurred on marginal agricultural lands (which has the advantage of both avoiding ecological disruption and reducing overall water consumption, when the solar facilities are PV-based), and at mid-scales, for which a growing diversity of urban installation sites have emerged, including parking lots and parking garages, business and school building rooftops, vacant lots, walking zones, and others.

- Customer Experience: Variations in solar design create radically different opportunities for experience on the part of end users. In the case of rooftop systems, for example, homeowners become participants in energy generation, often fre- 
quently checking their level of production, learning about energy, and even competing with one another to see who is producing more electricity (Noll et al. 2014). For utility-scale systems, on the other hand, customers of solar electrons often never know they are users of solar systems or, at best, if they've bought into a green energy program, get a small adjustment on their bill.

Given the variability across these models, it is perhaps not surprising that even subtle, seemingly small changes in socio-energy system design can create significant shifts in social outcomes. Consider rooftop solar systems. Typically on the scale of 3-7 kW, rooftop solar systems have become increasingly popular among homeowners in Arizona. Subsidized by utilities under the state's renewable portfolio standard starting at roughly $\$ 4 / \mathrm{W}$, rooftop systems were initially sold as purchased systems (with costs averaging $\$ 20,000-\$ 30,000)$ to homeowners. Since 2010 , however, a new model has emerged in which companies such as Solar City lease systems to homeowners. The technology itself is virtually identical, and the overall costs and financial benefits of each model are essentially the same, but the distribution of costs and benefits is different among key groups, including homeowners, utilities, ratepayers, leasing companies, and financial markets. Basically, the leasing model shifts some to all of the up-front costs of purchasing a system to the leasing company and its financial backers in exchange for some of the financial benefits derived. Two major outcomes have followed: the leasing model has quickly become the preferred model among homeowners, and the number of rooftop systems deployed in Arizona has grown rapidly.

These outcomes are important, from a socio-energy systems perspective, for two reasons. First, the rapid acceleration of rooftop adoption associated with the leasing mod- 
el has made much more visible for utilities the specter that rooftop systems will significantly eat into utility revenue streams and shareholder value, diverting the financial benefits of energy production from utilities to homeowners and leasing companies. Arizona utilities, in turn, have fought back, seeking approval from regulators to impose additional costs on leased systems and lobbying for equal treatment under property tax rules, both of which would reduce the financial benefits of rooftop solar systems. The result has been sustained political conflict that shows no sign of abating anytime soon. Future developments will determine whether solar rooftop systems will continue to reduce utility revenues and shareholder value and raise rates for utility customers (Satchwell et al. 2014) _ potentially undermining their long-term viability as businesses (Graffy and Kihm 2014) - or whether the rapid pace of solar rooftop adoption will slow in the state, allowing utilities to essentially retain monopoly control over electricity generation.

The second reason the outcomes of solar choices are important when looked at through a socio-energy systems lens is that they have potentially significant equity implications. As Figure 1 shows, while rooftop solar can be found in almost all zip codes of the city of Phoenix, AZ, people living in zip codes with higher median value homes have, on average, derived significantly greater financial benefit from solar systems. These zip codes have both higher numbers of systems and, on average, larger rooftop systems. This means not only that wealthier households are deriving greater financial advantage from becoming more energy independent but also that (1) those gains were subsidized by poorer ratepayers, who contributed to the pool of subsidies that helped finance these systems; and (2) that ratepayers who cannot afford to go solar themselves may face higher rates in the future as wealthier households defect from the utility and no longer pay as 
much as before toward the maintenance of the electricity grid. Utility shareholders, the majority of whom are retirees, also stand to take an economic hit if utility business models are impacted by continuing solar investment. These challenges remain even in leasing models, which theoretically lower the up-front costs of rooftop systems to zero, as wealthier households are more likely to own homes, have the high credit scores necessary to secure leases, and be able to take advantage of lease pre-pay options that increase the financial benefits of leasing. None of these are reasons to oppose solar energy. These outcomes are not inevitable with solar energy. Rather, they are defects in socio-energy system design that could be corrected through proper energy policy choices.

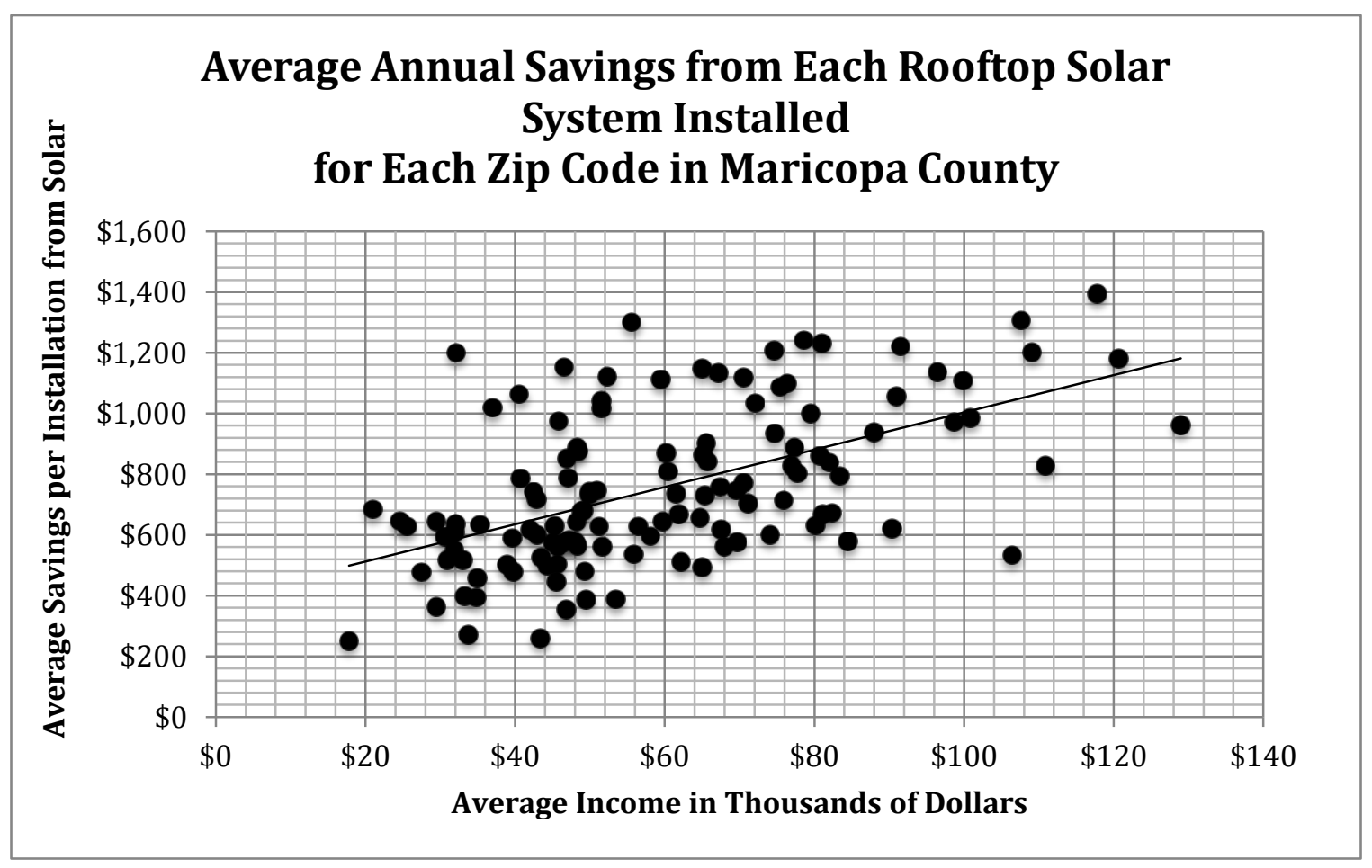

Figure 1. Average annual savings per household from installed rooftop solar systems, for each zip code in the Phoenix metropolitan region, as a function of the average income of households in that zip code. Data from arizonagoessolar.org, a database of solar installations maintained by the state's electric utilities, analyzed by Jason O'Leary and Clark Miller. 


\subsection{Design Choice \#2: Which Infrastructure, Which Community?}

The United States has experienced a boom in oil and gas extraction over the past decade, creating new regions of economic growth, social unrest, and environmental issues that are inherent to many socio-energy systems. This growth has occurred primarily from horizontal hydraulic fracturing of oil and gas in new regions of the country where drilling was previously unprofitable. This boom has been touted as a major success for US energy policy, as measured by traditional energy policy indicators such as lower oil prices, improved trade balances, investments in technology and infrastructure, and a significant number of relatively high paying jobs in the oil sector. Yet the US oil boom also illustrates that, when considered from a perspective of socio-energy system design, social complexities arise that should be taken into account in policy decisions. Our point is not to deny the successes of recent US oil policy, although there are reasons to do so, such as the long-term implications for carbon emissions. Rather, we emphasize that, with a socioenergy systems design framing, policy makers are positioned to anticipate and account for the full range of social outcomes and risks attendant to rapid growth of the oil industry.

One illustration of this can be seen in choices between forms of energy transport infrastructure. Historical analyses demonstrate that different transportation infrastructures can create different patterns of regional socio-economic development. In the late $19^{\text {th }}$ century, in the Northeastern United States, for example, historian Christopher Jones has shown that the growth of canals for transporting coal, transmission lines for carrying electricity, and pipelines for carrying oil all generated jobs in energy producing regions, and all three contributed to economic growth in cities along the coast. Only the canals, 
however, led to vibrant social and economic growth in the small towns and cities that lined canal routes, as barges not only stopped routinely in their travels but also carried other trade goods at the same time (Jones 2014, 2013).

The State Department Environmental Impact Statement for the Keystone XL suggests that the US is currently experiencing similar dynamics with regard to oil transport from Canada's tar sands to Gulf Coast refineries. The lack of adequate pipeline capacity has created a strong demand to expand rail traffic and supporting infrastructure along the same corridor. Like canals, railroads create a very different distribution of social and economic benefits (and risks, e.g., of accidents, see below) to pipelines. Similar to canal systems in the 1800 's, the construction of new rail terminals has generated not only construction jobs but also operations and maintenance jobs along the rail route, as well as generating hotel and other business for rail employees as they travel. Trains can also transport other trade goods at the same time (Department of State 2014). Should the Keystone XL pipeline be built, these benefits will vanish.

A perhaps more significant illustration of the benefits of a socio-energy systems lens is the current lack of social planning for communities in new oil and gas producing regions. Many communities around the country, and especially those surrounding the Bakken formation in Montana and North Dakota, have seen major changes associated with the build-up of energy operations. These changes include a significant growth in employment, although as with the case of large-scale solar plants built in rural or desert areas, workers are often imported into these regions rather than drawn from local populaces. The rapid growth (and sometimes subsequent rapid decline) in migrant workers often significantly strains local infrastructures, especially housing and social services. 
Communities in the Bakken formation are already confronting an influx of tens of thousands of workers throughout the supply chain, and as a result, have experienced significant increases in drug use and crime, rising costs of living, and changes in community dynamics. These are highly predictable problems, yet little planning has been done to deal with them, due to an exclusive focus on jobs and economic activity. Environmental and safety concerns also affect the boomtowns and their residents. Local road infrastructures experience significantly higher volumes of traffic and, especially, higher volumes of large truck use. On December $30^{\text {th }}, 2013$, a train carrying oil derailed and caught fire near Casselton, ND. The subsequent fireball resulted in the evacuation of 2,400 residents from their homes. Following this trend of increased oil-transport via rail, there have been several other similar accidents, some resulting in loss of life and property. Similar examples can be seen in Pennsylvania involving workers on the Marcellus shale formation and their impact on local infrastructures. Heavy trucking is required for nearly every part of the well drilling process in rural communities. A recent study by researchers at Rand Corp. shows that the cost of damage to state roads was between $\$ 13,000$ and $\$ 23,000$ per well in 2011. While shale firms have some agreements to repair roads that are visibly damaged, not all roads are effectively covered (Abramson et al. 2014).

Perhaps most perniciously, a study of social support institutions in North Dakota found that communities have faced pervasive social disruptions that make life difficult, especially for the poorest and most vulnerable within communities. Low-income individuals and families have been forced out by high rent costs, while others have seen rising rents eat away at their available income for food and other necessities. Many people live 
in substandard housing or in their vehicles, and social services and police are seeing rapid rises in domestic violence and the need for child protective services (Weber et al. 2014).

While these facets of energy development may simply be viewed as the inevitable downsides of an otherwise good deal for communities in energy producing regions, proper socio-energy system design and analysis could contribute to policies that improve social outcomes in boom communities, especially with regard to mitigating some of the worst impacts on communities while ensuring that new energy wealth contributes to long-term economic gains rather than short-cycle economic booms and busts. To the extent that future energy policy continues to neglect these often easily anticipated social consequences of energy production in accounting for the costs of oil, similar patterns of social unrest and unequal distribution of risks and benefits are likely to continue.

\subsection{Design Choice \#3: Which Waste Storage, Whose Voices?}

Policy choices surrounding nuclear energy waste disposal offer a third example of the value of approaching energy policy as a problem of socio-energy system design. Nuclear energy produces $20 \%$ of electricity in the United States, and will continue to be an important part of the national energy portfolio. However, even as nuclear waste is produced in this process, there is still no comprehensive national plan for the 70,000 metric tons of nuclear waste that has been produced from the nuclear fuel cycle. Currently, spent nuclear fuel (SNF) is stored in spent fuel ponds for five years. After this period, it is supposed to be moved to a national repository. This repository has yet to be built, however, and in 2008, the preferred choice, Yucca Mountain, was closed, leaving the waste in limbo. Instead, SNF is stored in dry casks in independent spent fuel storage installations 
(ISISIs), which are located at 54 reactor sites (NRC 2014). A third alternative is the reprocessing of spent nuclear fuel.

Looked at through a socio-energy systems design lens, each of these methods of handling nuclear waste creates its own geography of risks, as well as socio-economic arrangements, that will distribute benefits and burdens across different communities. Onsite storage is the current model for storing nuclear waste at the 65 nuclear plants across the United States, although it was never intended to be a permanent solution. Each of these sites presents a safety risk to nearby communities in terms of leaks of radioactive materials, security risks, e.g. from terrorist attacks, or natural hazards like earthquakes or floods. The thirty-foot casks are a striking visual reminder of the risks facing communities who were assured that a centralized SNF site would be created to solve the problem of nuclear waste. Citizen groups have pressed for hardened on-site storage which would increase the distance between casks and provide additional cover with concrete and steel in order to protect the casks from attacks, accidents, or leaks. The Nuclear Regulatory Commission (NRC) has stated, however, that they see no reason to change how casks are stored. Additionally, the NRC has begun a process to extend licenses for up to 120 years for dry casks, reflecting the fact that long term central storage is still a long way off (NRC 2014).

A second method is geologic storage of spent nuclear fuel. Geologic storage offers the prospects of concentrating the long-term risks of radioactive wastes in a single, ideally designed and located facility — although this image is complicated considerably by the fact that waste would need to be transported from reactors to the site, thus significantly expanding the potential geography of risks to unwitting and perhaps unwilling com- 
munities along transport routes. The present state of geologic disposal in the United States is mired in controversies stemming from the 1982 Nuclear Waste Policy Act (NWPA). For thirty years, NWPA planning focused on Yucca Mountain as one of two federal repositories required by the law. Yet, in 2008, plans for the Yucca Mountain facility were shut down in the face of strong opposition from diverse local communities, ongoing scientific controversy over the risks of geologic storage, and continued political opposition to nuclear power among many environmental groups (Shrader-Frechette 2014, Walker 2009). Geologic disposal of nuclear waste also raises complex questions about intergenerational considerations. While sequestering nuclear waste from humans is seemingly technically straightforward in the present, uncertainty surrounding future longterm changes in human developments and needs, as well as environmental conditions, significantly complicates attempts to do so over the 10,000 years required by the Environmental Protection Agency for geologic repositories in the United States (McFarlane 2006). New ways of engaging with the public may offer insights into future debates over nuclear waste, including the Blue Ribbon Commission's recommendation that the NRC should focus on areas where communities in locations deemed geologically appropriate are willing to step forth and host waste sites, and a similar initiative is emerging in the U.K. that focuses on voluntary communities and suitable geologies, although how to define those qualifiers still needs to be debated (Blue Ribbon Commission 2012, Bickerstaff 2012).

A third avenue for dealing with SNF is reprocessing. The US currently employs a "once through" process of using nuclear fuel, meaning the SNF from energy production is used only once, and then removed and replaced with new fuel during the refueling 
process. A "closed fuel" cycle would reuse the SNF in another kind of reactor that separates useful uranium from other by-products. Like a geologic repository, reprocessing would centralize waste handling, with a transport system from individual power plants, and thus create similar risks from accidents or attacks at the reprocessing site or during travel to and from power plants, the reprocessing facility, and the long-term repository that would still be required to store the final waste from reprocessing (although this would involve a much smaller volume of final waste). One proposal is to develop an energy park at Yucca Mountain where nuclear experiments such as reprocessing could be carried out. Instead of an eternal tomb for the radioactive waste produced by nuclear energy, Yucca Mountain would become a place for producing beneficial technologies (US Government Accountability Office 2011). Yet, this proposal addresses none of the social and political concerns that prevented Yucca from opening. At the same time, reprocessing brings a very different set of risks. One of the principle socio-political concerns with reprocessing SNF is that it produces radioactive materials that may increase the risk of proliferation of nuclear weapons, one of the main reasons the US decided to forgo reprocessing in 1977.

These three possibilities for nuclear waste demonstrate that questions of social justice are inherent in choices about where and how to store nuclear waste, including the creation of nuclear communities near sites or along transportation routes, the development of expertise required to manage and maintain facilities, and security issues from local to global scales. It also opens up questions about what ethical and moral obligations present communities have to future generations, who will live with nuclear waste sites though they may not benefit from nuclear energy. Examining the social worlds that each 
approach would bring into being offers a richer backdrop for planning for future nuclear activity, as well as acknowledging that the back-end of the fuel cycle requires more foresight than previously afforded to it.

\section{Bring Socio-Energy System Design into Energy Policy and Governance}

How can the framework of socio-energy system design be effectively incorporated into energy policy and governance? This entails two tasks: (1) rethinking the object of energy policy, as we have discussed so far; and (2) configuring new approaches to energy policy and governance that can more effectively integrate the human and social dimensions of energy systems into energy analyses and choices. For our purposes here, we define energy policy and governance broadly, as not merely policy choices about energy but the processes and institutional arrangements through which policy choices are informed, made, and implemented. Thus, we include at least three significant domains of work in our definition of energy policy and governance: (1) the practices and techniques through which potential energy futures are envisioned, modeled, analyzed, and evaluated; (2) the forums and methods for deliberating, debating, and making energy choices; and (3) the institutions for fashioning, operating, and regulating new energy systems. Cutting across these three domains, we see four significant avenues for transforming energy policy into processes and practices for socio-energy system design.

\subsection{Socializing Energy Policy}

First, reconfiguring energy policy as socio-energy design requires new strategies for integrating the human and social dimensions of socio-energy systems into processes of ener- 
gy design, planning, and policy-making. This requires understanding, acknowledging, and incorporating the ways in which people inhabit energy systems: as residents, consumers, workers, investors, managers, etc. We must learn to better document, visualize, and analyze socio-energy systems, to anticipate how such systems may change as part of energy transitions, and to envision alternate possibilities to inform energy policy deliberations. This will require new methods and models, new forms of expertise, and the addition of new disciplines to the mix of energy research and policy analysis, with a particular emphasis on finding strategies to bring specialists in the human and social sciences into the field of energy and the practice of energy policy. Learning to imagine, conceptualize, analyze, evaluate, and deliberate energy policy in terms of socio-energy systems will require complex methods of observation and analysis. Of special significance will be the role of research funding institutions that are positioned to build both new knowledge tools and the necessary human resources to advance the social sciences of energy, but whose deep neglect of research in these fields to date undermines the ability of countries to pursue intelligent social planning for energy transitions.

We believe three areas of knowledge advances are particularly significant at the outset. The first is the capacity to theorize and model socio-energy systems, fully integrating people into our understanding of supply chains, energy operations, and the social values, behaviors, relationships, networks, and institutions fashioned around the use of diverse kinds of energy — and the opportunities for social change that accompany significant changes in energy technologies and markets. A key element of such models will be to track and explain the social dynamics of energy systems (Noll et al. 2014). Approaches will be needed to explore how people become embedded into and disciplined into these 
systems and the subsequent implications for human imaginations, identities, and institutions. In order to remain safe in today's world, for example, children must be rigorously and carefully trained to behave in certain ways around energy systems (cars, electricity outlets, power cords, etc.). Likewise, people's understanding of the world is shaped by energy regimes. Adults become accustomed to thinking of themselves as elements of energy systems, for example, in turn rethinking their relationships with one another, with institutions, with societies, and with places. People who understand what a car is, know how to drive one, and either own or are able to access one generally view space, geography, and distance in radically different ways from others who do not share these same characteristics. Even for inhabitants of major cities with extensive and easy-to-use public transportation systems, like Boston, owning a vehicle transforms the city into a fundamentally different landscape with radically different geographies of accessibility.

The second is to significantly deepen understanding of the social outcomes that flow from energy policy choices and technology arrangements. New methods will need to be developed that focus on identifying, mapping, and measuring significant social outcomes from energy choices across a wide range of human affairs. As a general proposition, we are able to say relatively little about the social consequences that flow from energy projects. It is striking, for example, that only one major study has sought to measure the social consequences of oil development in the Bakken Formation (Weber et al. 2014). From a more predictive perspective, a similar problem bedevils energy as a tool for human development. For over a half-century, economic theories have highlighted the significance of energy inputs as a crucial facet of human development. Yet, strikingly, we know relatively about how energy contributes to specific human development outcomes, 
especially at the community level. Moreover, we know even less about how the design of energy technologies and the kinds of social and economic arrangements we build around them enable or constrain the ability of communities to advance different facets of human development (Poor People's Energy Outlook 2014). Such insights are critical if we are to make significant progress on developing energy systems that deliver high social value and thus contribute to advancing development goals in a significant way. A recent World Bank report highlights that energy development in regions that do not currently have electricity in Africa will remain expensive (Tenenbaum et al. 2014). All the more reason, therefore, to develop the knowledge necessary to ensure that the energy projects we do invest contribute to significant improvements in social outcomes.

Perhaps most significantly, third, strategies will need to be developed to map how complex socio-economic arrangements distribute the costs and benefits of energy production and consumption in highly heterogeneous ways across contemporary societies. The field of environmental justice demonstrates that in the context of large-scale energy transitions, understanding how subtle changes in social meaning, identity, or power relationships, especially in the context of differences in race and gender, are affected by energy systems is extremely important (Schlossberg 2007, Kurtz 2010, Ralston 2014, Ryan 2014). Designing and developing just energy systems requires attending to how these factors are distributed across different physical, social, cultural, and economic geographies. Only through such knowledge will energy policy be able to address the forms of injustice that have led in recent years to high profile social resistance to efforts to bring about energy transitions. 


\subsection{Systematizing Energy Policy}

The second significant demand on energy policy in the context of major energy transitions is to extend and expand institutional capacities to analyze and govern energy on a system-wide, lifecycle basis. It is difficult if not impossible to imagine the possibility of contemplating socio-energy system design absent the capacity to think, analyze, and act in systemic terms. Our assertion may come as a surprise to some who think that energy policy already encompasses a great deal of systems thinking and perspectives. In some respects, this is true. Energy systems analyses are common, especially in academic research. Organizations like the International Energy Agency and US Energy Information Agency tend to operate at a systems level, although their data is often broken down by country or by state in a far less systematic fashion. Yet, current energy systems approaches fall short in two crucial ways. First, they tend to limit energy systems to their technological elements, neglecting to treat the social and political dimensions of energy equally robustly in systems terms. Second, energy policy and governance rarely follows systemic organization. That is, we rarely govern whole energy systems in a comprehensive fashion. Instead, energy policy and governance are conducted piecemeal, whether in terms of geography, sector, or scale, creating headaches for cross-jurisdictional coordination and orchestration.

In the United States, as an illustration, neither the federal government nor state governments have integrated energy agencies responsible in a comprehensive fashion for energy development, energy system management, or energy policy. Given the deep significance of energy for economic development and social organization, this is perhaps not surprising but nevertheless creates widespread difficulties for approaching energy policy 
as a problem of socio-energy system design. One consequent shortcoming is the general absence of strategic energy planning. Strikingly, for example, many states, confronted with the prospect of new EPA rules requiring reductions in state carbon emissions from electricity generation, face two significant problems. First, little to no data exists on state energy systems, except in terms of aggregate figures. Instead, understanding of energy systems tends to be isolated on a utility-by-utility basis. Second, energy systems cut across state boundaries in substantial ways, with utilities routinely depending on generating facilities in other states, subject to energy policy there.

Public utilities commissions in the United States have begun, recently, to encourage utilities to pursue integrated resource planning. Yet, in the context of current energy transitions, that is often inadequate. Electricity trading among utilities and independent power producers is on the rise. Access to resources for energy production, such as land and water, may become competitive. Perhaps most importantly, growth in electric and natural gas vehicles may soon compel the need to plan across the electricity, fuel, and natural gas sectors, something which is not routinely done in most parts of the country.

The absence of a capacity for strategic planning and systems governance becomes particularly true when we look at questions of socio-energy design in the context of energy resource development. Whether the subject is vehicle charging stations, power plant siting, or mineral rights leases, the common tendency to approach energy policy and decision-making on a case-by-case basis often leads to problematic outcomes from the perspective of socio-energy system design. Communities dealing with natural gas drilling have found it particularly difficult to plan for the impacts of drilling (e.g., road use, influx of new labor) and to ensure appropriate consideration of a variety of concerns (e.g., risk 
assessment and monitoring) in the absence of institutional or legal capacities to carry out a community-wide approach to energy policy decisions. Instead, they have confronted an environment in which landholders hold the rights to negotiate leases, with communities bearing the collective consequences of a host of uncoordinated individual decisions. A 2014 ban on hydraulic fracturing in Denton, TX, for example, has been challenged on the basis that it infringes local property owners' rights to exploit the resources they own. This framework for energy policy often also serves to facilitate the energy industry's ability to negotiate lower compensation levels for landowners by negotiating separately and secretly.

The case of power plant siting also offers an illustration of the problem of both a lack of systems analysis and system-wide policy. In siting new power plants, utilities or other companies typically select sites and initial designs for plants, negotiate land deals, and set up transmission line agreements before informing the public of a proposal to build a new facility. This process creates a strong tendency to lock in energy technology and economic designs, except at the margins, as it becomes extremely difficult for the policy process to reopen major design criteria. In turn, this precludes consideration of significant socio-energy design alternatives, such as building a different kind of plant, in a different location, or taking an entirely different path to meeting demand growth, such as increasing energy efficiency. Given that the primary benefits of a socio-energy design perspective come from being able to look broadly at alternative designs and design criteria, these benefits are unlikely to be realized via existing siting practices. 


\subsection{Publicizing Energy Policy}

Enlarging the view of energy policy to encompass the project of socio-energy systems design naturally raises questions about who participates in the new expanded policy processes that this will inevitably entail. Socializing and systematizing energy policy, as described in the prior sections, arguably both expand the array of stakeholders who are likely to consider energy system development as within their scope of interest, especially in the context of large-scale energy transitions that may fundamentally transform the social and physical geographies of energy production and consumption. In fact, publics are already well aware of this and increasingly demanding a seat at the energy policy table (Devine-Wright 2011, Abramsky 2010). Even with public input in many federal projects due to a required public comment period, meaningful interactions between experts and lay-people remains difficult, and the incorporation of public ideas and concerns into policy processes in a systematic_-or system-wide — fashion is lacking.

Conceptually, the challenge is to create energy policy processes that encompass the envisioning, designing, deliberating, choosing, and making of future socio-energy systems and render possible partnerships between the energy industry and communities at all of these stages. This, of course, is an immensely difficult undertaking even to imagine, let alone to implement successfully. Part of the challenge is to develop new methodologies for envisioning future energy pathways on multiple scales and temporalities. Another part of the problem is the current dearth of opportunities available to communities to become engaged in the design and deliberation of energy futures. Existing energy policy processes, from power plant and transmission siting processes to the design of major na- 
tional legislation, tend to limit rather than expand public participation and engagement. These limits — in the energy policy process as currently constituted — include everything from the presumed levels of expertise entailed in energy policy debates to the forms and timing of public comments and feedback to the dissecting and distribution of energy policy choices across multiple agencies and jurisdictions. The result is a system that, in many ways, is largely opaque to the public and that the public is allowed (or perhaps encouraged) to systematically ignore.

In contrast to conventional energy policy processes, France has embarked over the past two years on a major review of its energy system and of the potential need to undertake a significant energy transition. This review began, perhaps surprisingly, with an extensive period of public debate, with over 170,000 people involved in diverse regional public forums (still small compared to the overall population of the country, but significantly larger than most exercises of public engagement in energy policy). While French public support for nuclear energy remains relatively strong (El Jammal et al. 2013) _ nuclear energy currently provides $75 \%$ of France's electricity - the public debate afforded a relatively unique opportunity for the public to reflect on and deliberate French energy strategy over the long-term. As a result of this referendum, the French government has decided to lessen its reliance on nuclear energy, with a goal of $50 \%$ of electricity production from nuclear by 2025 , compensated for by a ramp up in the production of renewable energy (World Nuclear News 2014).

In a similar, if dramatically less ambitious exercise, the state of Arizona has also pursued a series of energy deliberations over the past several years. The first such deliberation was led by a non-governmental organization, Arizona Town Hall, which has orga- 
nized public debates about major policy issues confronting the state for the past half century. The event, held in Fall 2011, involved approximately 150 business, policy, and civic leaders in a three-day deliberative exercise and resulted in a set of policy recommendations that were subsequently distributed across the state. The strongest recommendation was for the development of a state energy plan, a task that was subsequently taken up by the Office of Energy within the Arizona Governor's Office. Working with a task force of energy industry leaders, the Governor's Office released a new energy plan for the state in February, 2014, focused on promoting solar energy, energy efficiency, and development of a strong energy workforce and industry. In thinking about different scales and perspectives, individual states in the US are an important node for expressing both local and national perspectives, which in turn may influence national energy policies and incorporate social and community values.

Events such as these are hardly a panacea for the challenges confronting energy policy in the coming decades. Involving publics in significant ways in efforts to redesign the energy system will require much more substantial initiatives, using innovative approaches to garnering public participation in everything from discussing energy scenarios to figuring out the details of novel energy systems. Yet the challenges of not engaging publics more effectively are also apparent. The energy system is so important to people's lives that significant changes to it are potentially enormously disruptive. Not surprisingly, therefore, even at relatively early stages in the coming energy transformation, as we write, nearly every currently plausible form of potential future energy system is at the center of significant social protests, political controversies, or both. It is not an accident that hydraulic fracturing is deeply opposed in the same communities that its use is enriching; 
that the process to site a nuclear repository at Yucca Mountain fell short; or that conservative Arizonans showed up en masse to protest efforts by utilities to significantly curtail solar rooftop development.

\subsection{Governing Energy Transitions}

Finally, energy policy going forward must recognize that the problems that confront energy policy and governance during times of large-scale and rapid transformation are qualitatively different than those at stake during times of stability or slow, incremental change. Here we identify only a few of what is likely to be a large array of important governance challenges that energy policy institutions and leaders will face.

One key governance challenge will be that of organizational change. For close to a century, the dominant organizational configuration of the electricity industry has been roughly stable, with large, centralized, monopoly utilities providing the bulk of electricity and dominating the management of electrical grids. Electricity deregulation has already brought significant organizational shifts to some regions, and the rise of distributed energy systems as a major potential electricity supply also poses challenges for this organizational model. As the utility sector recognizes, distributed energy generation undermines key elements of the existing financial and technological models of the electricity system. Energy policy must thus confront head on the question of how to organize electricity production and distribution going forward.

A second challenge is to find ways to maintain and strengthen public confidence in the transition process. Energy transitions have the potential to bring deep uncertainties to a wide variety of stakeholders, from utilities to regulators to publics. Energy policy 
processes need to recognize, acknowledge, and confront directly this challenge - which is at least in part a problem of trust in those managing the process-lest uncertainties lead to policy or political stalemate. In 1993, for example, the Clinton Administration proposed raising gasoline taxes by a small amount to begin funding climate solutions. The proposed taxes have been far outstripped by subsequent actual change in gas prices, yet uncertainties about how climate policies would ultimately distribute the burdens of transforming the energy system led to widespread opposition to the proposals. Especially in the context of a system so consequential to people's lives and livelihoods as energy, managing the governance process to avoid public disaffection and defection is a key problem.

Related to the problem of trust is the problem of managing social dislocations associated with large-scale energy system change. Energy systems are embedded in and across a wide range of diverse communities, and large-scale changes in those systems are likely to have significant consequences for many of those communities. This is obvious in the case of energy producing regions, like coal mining communities or, especially, the Middle East or the Gulf Coast of the US. These regions are likely to be decimated by declining use of fossil fuels, unless appropriate policies are developed ahead of time to manage social and economic dislocation. In other cases, the consequences may be less obvious and direct, but may be just as severe. Many utilities, for example, are seen as relatively safe investments for retirement investment portfolios. In fact, a significant majority of utility stock is owned by retirees. If the threat to utility business models from distributed energy is as significant as some in the utility industry now fear, utility stock owners are likely to suffer significant investment losses. 
A final challenge is the orchestration and management of the consequences of energy changes that flow across jurisdictions. Energy policy and governance comprise a tangled thicket of overlapping and non-overlapping jurisdictions, both geographically and institutionally. Energy systems cut through this thicket in complex and often unanticipated ways. Changes in energy systems are thus likely to have consequences far beyond their point of origin. Unless energy policy and governance institutions can find ways to better coordinate their decision-making across these thickets, the result is likely to be less than optimal policy solutions that carry enormous and unconsidered implications for diverse communities across the face of the planet.

\section{Conclusion}

We have used the word "inhabit" several times in this article to describe the social dimensions of energy systems. Whether it has ever been different, people today literally inhabit energy systems. They live with, in, around, and through energy - in the process both constituting energy systems and being constituted by them. Energy shapes — and is shaped by_people's economies, workplaces, identities, environments, technologies, landscapes, politics, and mental maps of the world. As the United States and the world contemplate a deep and widespread energy transition over the next few decadeswhether toward new forms of hydrocarbons, a nuclear resurgence, renewables, or something else entirely - this transformation will have enormous human consequences. At least for the purposes of this transition, energy policy must expand to acknowledge, recognize, assess, and incorporate the fact that its objectives and outcomes are not just to change either the fuels or technologies of energy but to transform socio-energy systems. 
Fundamentally what we are arguing for in this article is a reconceptualization of the energy policy imagination — of the kinds of things we think about, consider, analyze, argue about, and take into consideration in the making of energy policy choices (Sovacool 2014, Jasanoff and Kim 2009). This is both an act of opening up our imagination of the world of energy to the full range of ways in which energy entrains and is entrained in human affairs; of differently disciplining the imagination through new forms of analytic tools, methods, and models; of differently organizing who is involved in energy decisions, at what points in the process, and in what ways; and of differently weighing the many facets of complex energy choices. As energy researchers, analysts, managers, regulators, and politicians, we must find ways to bring the full breadth of the human and social dimensions of energy transitions into our day-to-day work in a robust and systematic fashion.

It is striking how impoverished we have let the imagination of our current forms of energy analysis and policy become. America's Energy Future may have been written by engineers, for the purpose of laying out our technological options going forward. Nonetheless, its title proclaims much, much more. As a document depicting America's energy future, it offers little insight into much else of importance in what energy will mean to the country a half century from today: the ways that we will inhabit future energy systems, the distribution of benefits that we will derive and risks and dangers that we will confront, the forms of labor and economic livelihood that will be enabled and disabled, the kinds of people that we will become, and the future possibilities that we will imagine for ourselves, our communities, and our world. These are the domains of imagi- 
nation that we must increasingly enter and master, if we are to justly and successfully navigate and govern the coming energy transition.

\author{
Acknowledgements \\ This material is based upon work primarily supported by the Engineering Research Cen- \\ ter Program of the National Science Foundation and the Office of Energy Efficiency and \\ Renewable Energy of the Department of Energy under NSF Cooperative Agreement No. \\ EEC-1041895. Any opinions, findings and conclusions or recommendations expressed in \\ this material are those of the author(s) and do not necessarily reflect those of the National \\ Science Foundation or Department of Energy.
}




\section{References}

Abramsky, K., ed. 2010. Sparking a Worldwide Energy Revolution. Oakland: AK Press. Abramson, S., Samaras, C., Curtright, A., Litovitz, A., and Burger, N. 2014. Estimating the Consumptive Use Costs of Shale Natural Gas Extraction on Pennsylvania Roadways. Journal of Infrastructure Systems 20(3): 06014001.

Bickerstaff, K. 2012. 'Because we've got history here': nuclear waste, cooperative siting, and the relational geography of a complex issue. Environment and Planning A 44: 26112628.

Bird, L., et al. 2013. Regulatory Considerations Associated with the Expanded Adoption of Distributed Solar. NREL/TP-6A20-60613. Boulder: National Renewable Energy Laboratory.

Blue Ribbon Commission for America's Nuclear Future. 2012. Report to the Secretary of Energy. Washington: Government Printing Office.

Chin, G., and Culotta, E. 2014. What the Numbers Tell Us. Science 344(6186): 818-821.

Cowan, R. 1983. More Work for Mother. New York: Basic Books.

Department of Energy, 2012. Quadrennial Technology Review.

http://energy.gov/downloads/quadrennial-technology-review-august-2012. Washington:

US Department of Energy. Downloaded: 9/30/14.

Department of State, 2014. Final Supplemental Environmental Impact Statement for the Keystone XL Project. Washington: US Department of State.

Devine-Wright, P., ed. 2011. Renewable Energy and the Public. London: Earthscan.

El Jammal, M. H., Rollinger, F., Mur, E., Schuler, M., and Tchernia, J. F. 2013. More Than 30 Years of Opinion of French People on Nuclear Risks-Special Release of the 2012 IRSN Opinion Survey. Fontenay-aux-Roses: Institut de Radioprotection et de Surete Nucleaire.

Elzen, B., Geels, F., and Green, K. 2004. System Innovation and the Transition to Sustainability. Cheltenham: Edward Elgar.

Geels, F. 2010. Ontologies, Socio-Technical Transitions (To Sustainability) and the Multi-Level Perspective. Research Policy 39: 495-510.

Geels, F., and Verhees, B. 2011. Cultural Legitimacy and Framing Struggles in Innovation Journeys: A Cultural-Performative Perspective and a Case Study of Dutch Nuclear Energy (1945-1986). Technological Forecasting and Social Change 78: 910-930.

Graffy, E., and Kihm, S. 2014. Does Disruptive Competition Mean a Death Spiral for Electric Utilities? Energy Law Journal 35: 1-219. 
Hecht, G. 2012. Being Nuclear: Africans and the Global Uranium Trade. Cambridge, MIT Press.

Hecht, G. 2011. Entangled Geographies: Empire and Technopolitics in the Global Cold War. Cambridge: MIT Press.

Hecht, G. 1998. The Radiance of France: Nuclear Power and Identity after World War II. Cambridge, MIT Press.

Hirsh, R., and Jones, C. 2014. History's Contribution to Energy Research and Policy. Energy Research and Social Science 1: 106-111.

Hirt, P. 2012. The Wired Northwest: The History of Electric Power, 1870s-1970s. University Press of Kansas.

Howarth, N. A., and Rosenow, J. 2014. Banning the Bulb: Institutional Evolution and the Phased Ban of Incandescent Lighting in Germany. Energy Policy 67: 737-746.

Huber, M. 2013. Lifeblood: Oil, Freedom, and the Forces of Capital. Minneapolis: Minnesota.

Hughes, T. 1983. Networks of Power: Electrification in Western Society, 1880-1930. Baltimore: Johns Hopkins University Press.

Insull S. 1915. Central Electric Station Service: Its Commercial Development and Economic Significance as Set Forth in the Public Addresses (1897-1914) of Samuel Insull. Chicago: Privately Printed.

Jasanoff, S. 2004. States of Knowledge. London: Routledge.

Jasanoff, S., and Kim, S-H. 2009. Containing the Atom: Sociotechnical Imaginaries and Nuclear Power in the United States and South Korea. Minerva 47: 119-146.

Jasanoff, S., and Kim, S-H. 2013. Sociotechnical Imaginaries and National Energy Policies. Science as Culture 22(2): 189-196.

Jones, C. 2013. Building More Just Energy Infrastructure: Lessons from the Past. Science as Culture 22(2): 157-163.

Jones, C. 2014. Routes of Power: Energy in Modern America. Cambridge: Harvard University Press.

Kurtz, H. 2010. Acknowledging the Racial State: An Agenda for Environmental Justice Research. In Holifield, R., Porter, M., Walker, G., eds. Spaces of Environmental Justice. West Sussex: Wiley-Blackwell.

Laird, F. 2013. Against Transitions? Uncovering Conflicts in Changing Energy Systems. Science as Culture 22(2): 149-156.

Leslie, S., and Hevly, B. 1985. Steeple Building at Stanford: Electrical Engineering, Physics, and Microwave Research. Proceedings of the IEEE 73(7): 1169-1180. 
Lovins, A. 2002. Small is Profitable: The Hidden Economic benefits of Making Electrical Resources the Right Size. Boulder, Rocky Mountain Institute.

Marathe, A., Marathe, M., Anil Kumar, V.S. 2011. Towards a Pervasive Enabled Modeling Environment for Integrated Coevolving Energy Systems. Proceedings of the 2011 IEEE EPU-CRIS International Conference on Science and Technology. November.

MacFarlane, A. 2006. Technical policy decision making in siting a high-level nuclear waste repository, in Uncertainty Underground: Yucca Mountain and the Nation's HighLevel Nuclear Waste. Cambridge: MIT Press.

Meyer, Niels I. 2007. Learning from Wind Energy Policy in the EU: Lessons from Denmark, Sweden and Spain. European Environment 17(5): 347-362.

Miller, C., Iles A., and Jones C. 2013. The Social Dimensions of Energy Transitions. Science as Culture 22(2): 135-148.

Miller, C. 2014. The Ethics of Energy Transitions. Proceedings of the 2014 IEEE International Symposium on Ethics in Science, Technology and Engineering. May.

Miller, C., and Richter, J. 2014. Social Planning for Energy Transitions. Current Sustainable/Renewable Energy Reports 1: 77-84.

Mitcham, C., and Rolston, J. S. 2013. Energy Constraints. Science and Engineering Ethics 19(2): 313-319.

Mitchell, T. 2011. Carbon Democracy: Political Power in the Age of Oil. London: Verso. Mulvaney, D. 2013. Opening the Black Box of Solar Energy Technologies: Exploring Tensions Between Innovation and Environmental Justice. Science as Culture 22(2): 230237.

National Academy of Engineering. 2008. America’s Energy Choices. Washington: National Academies Press.

Noll, D., Dawes, C., and Rai, V. 2014. Solar Community Organizations and Active Peer Effects in the Adoption of Residential PV. Energy Policy 67: 330-343.

NRC. 2014. Storage of spent nuclear fuel. Washington: Nuclear Regulatory Commission. http://www.nrc.gov/waste/spent-fuel-storage.html. http://www.nrc.gov/waste/spent-fuelstorage/faqs.html. Downloaded: 9/30/14.

Nye, D. 1999. Consuming Power: A Social History of American Energies. Cambridge, MIT Press.

Nye, D. 1990. Electrifying America: Social Meanings of a New Technology, 1880-1940. Cambridge, MIT Press.

Ottinger, G. 2013. Refining Expertise: How Responsible Engineers Subvert Environmental Justice Challenges. New York: NYU Press. 
Perrow, C. 1984. Normal Accidents. Princeton: Princeton University Press.

Poor People's Energy Outlook. 2014. Bourton on Dunsmore: Practical Action.

Richter, J. 2013. New Mexico's Nuclear Enchantment: Local Politics, National Imperatives, and Radioactive Waste Disposal. PhD Dissertation. University of New Mexico.

Rolston, J. 2014. Mining Coal and Undermining Gender: Rhythms of Work and Family in the American West. New Brunswick, Rutgers University Press.

Rucinski, T., and Kaye, B. 2014. Taxes, Fees: The Worldwide Battle Between Utilities and Solar. http://www.reuters.com/assets/print?aid=USKCN0HN07P20140929. Downloaded 9/30/14.

Ryan, S. 2014. Rethinking gender and identity in energy studies. Energy Research and Social Science 1: 96-105.

Satchwell, A., et al. 2014. Financial Impacts of Net-Metered PV on Utilities and Ratepayers: A Scoping Study of Two Prototypical U.S. Utilities. Berkeley: Lawrence Berkeley National Laboratory. http://emp.lbl.gov/sites/all/files/LBNL\%20PV\%20Business\%20Models\%20Report_no\% 20report\%20number_0.pdf. Downloaded: 9/30/14.

Schlossberg, D. 2007. Defining Environmental Justice: Theories, Movements, and Nature. Oxford: Oxford University Press.

Sen, A. 1983. Poverty and Famines. Oxford: Oxford University Press.

Shrader-Frechette, K.S. 2014. Tainted: How Philosophy of Science Can Expose Bad Science. Oxford, Oxford University Press.

Smith, M.R., 1994. Technological Determinism in American Culture. In Smith, M.R., and Marx, L., eds., Does Technology Drive History? Cambridge: MIT Press, pp. 1-35.

Sovacool, B., 2014. What are We Doing Here? Analyzing Fifteen Years of Energy Scholarship and Proposing a Social Science Research Agenda. Energy Research and Social Science 1: 1-29.

Sovacool, B., and B. Brossman. 2013. Fantastic Futures and Three American Energy Transitions. Science as Culture 22(2): 204-212.

Steinberger, Julia K., and J. Timmons Roberts. 2010. From Constraint to Sufficiency: The Decoupling of Energy and Carbon from Human Needs, 1975-2005. Ecological Economics 70(2): 425-33.

Tenenbaum, B., et al. 2014. From the Bottom Up: How Small Power Producers and Mini-Grids Can Deliver Electrification and Renewable Energy in Africa. Washington: World Bank. https://openknowledge.worldbank.org/handle/10986/16571. Downloaded: 9/30/14. 
Trutnevyte, E., Stauffacher, M., \& Scholz, R. 2011. Supporting Energy Initiatives in Small Communities by Linking Visions with Energy Scenarios and Multi-Criteria Assessment. Energy Policy 39(12): 7884-7895.

US Government Accountability Office. 2011. Yucca Mountain: Information on Alternative Uses of the Site and Related Challenges. Washington: Government Accountability Office. http://www.gao.gov/products/GAO-11-847. Downloaded: 9/30/14.

Wagner, P., and Wittrock, B. 1991. States, Institutions, and Discourses: A Comparative Perspective on the Structuration of the Social Sciences. In Wagner, P., Wittrock, B., and Whitley, R. P., eds. Discourses on Society: The Shaping of the Social Science Disciplines, Vol. 15. Dordrecht: Springer.

Walker, J.S. 2009. The Road to Yucca Mountain: The Development of Radioactive Waste policy in the United States. Berkeley, The University of California Press.

Weber, B., Geigle, J., Barkdull, C. 2014. Rural North Dakota's Oil Boom and its Impact on the Social Services. Social Work 59(1): 62-72.

World Nuclear News. 2014. New French Energy Policy to Limit Nuclear. http://www.world-nuclear-news.org/NP-New-French-energy-policy-to-limit-nuclear1806144.html. Downloaded 07/01/14.

Wüstenhagen, R., Wolsink, M., \& Bürer, M. 2007. Social Acceptance of Renewable Energy Innovation: An Introduction to the Concept. Energy Policy 35(5): 2683-2691.

Wynne, B. (2005). Risk as Globalizing 'Democratic' Discourse? Framing Subjects and Citizens. In Leach, M., Scoones, I., and Wynne, B. Science and Citizens. London: Zed Books, pp. 66-82.

Zimmerer, K. 2011. New Geographies of Energy: Introduction to the Special Issue. Annals of the Association of American Geographers 101(4): 705-711. 